\title{
Kroppsøvingslæreren som en inkluderende pedagog $i$ skjæringspunktet mellom individ og samfunn
}

\author{
Knut Westlie` og Kjersti Mordal Moen \\ Høgskolen $i$ Innlandet
}

\section{Sammendrag}

Forskning har vist at kroppsøvingsfaget favoriserer enkelte elevgrupper og marginaliserer andre (se f. eks. Dowling, 2016; Fitzpatrick, 2013; Gerdin et al., 2019; Öhman, Almqvist \& Meckbach, 2014). Denne artikkelen baserer seg på data fra et internasjonalt forskningssamarbeid mellom forskere fra New Zealand, Sverige og Norge; EDUHEALTH. Prosjektet har som mål, gjennom et «bottom-up» perspektiv, å studere de presumptivt gode eksemplene på kroppsøvingslærere som jobber sosialt inkluderende i faget. Dette er lærere som anerkjenner sosiale bakgrunnsvariabler og sosial ulikhet, og som tar høyde for dette i sin undervisning for å skape inkludering snarere enn utenforskap. Denne artikkelen bygger på observasjon (Critical Incident Technique) og intervju (Stimulated-Recall Interview) med én kroppsøvingslærer i New Zealand. Vi har benyttet Bronfenbrenners utviklingsøkologiske modell som analytisk rammeverk. Våre analyser viser at lærerens inkluderende handlingsvalg $\mathrm{i}$ undervisningen springer ut fra faglige refleksjoner basert på kunnskap om elevene i skjæringspunktet mellom individ og samfunn. Våre funn viser med andre ord at inkluderende undervisning er både en praksis og en prosess som krever refleksjon på mikro-, meso-, ekso- og makronivå.

Nøkkelord: Skole; respekt; omsorg; sosial inkludering; kroppsøving; Bronfenbrenner

\begin{abstract}
The physical education teacher as an inclusive educator at the intersection of individual and society

Previous research has shown that Physical Education (PE) favors some student groups and marginalizes others (e.g., Dowling, 2016; Fitzpatrick, 2013; Gerdin et al., 2019; Öhman, Almqvist \& Meckbach, 2014). This article is based on data from an international research collaboration between researchers from New Zealand, Sweden and Norway; EDUHEALTH. The purpose of the project is, through a "bottom-up" perspective, to study the presumptively good examples of physical education teachers who teach in a socially inclusive way. The teachers in this study recognize that social background variables and social inequality matter, and take this into account in their teaching to create
\end{abstract}

\footnotetext{
^Korrespondanse: Knut Westlie, epost: knut.westlie@inn.no

(C) 2020 K. Westlie og K. M. Moen. This is an Open Access article distributed under the terms of the Creative Commons Attribution 4.0 International License (https://creativecommons.org/licenses/by-nc/4.0/), allowing third parties to copy and redistribute the material in any medium or format and to remix, transform, and build upon the material for any purpose, even commercially, provided the original work is properly cited and states its license. 
social inclusion in PE. Data in this article are based on observation (Critical Incident Technique) and interview (Stimulated-Recall Interview) with one physical education teacher in New Zealand. Drawing on Bronfenbrenner's Ecological Systems Theory, our analyses show that the teacher's inclusive choices of action are rooted in reflections based on knowledge about the students in the juncture between the individual and the society. In other words, our findings show that inclusive teaching is both a practice and a process that requires reflection at the micro, meso, exo and macro levels.

Keywords: School; respect; care; social inclusion; physical education (PE); Bronfenbrenner

Received: December, 2018; Accepted: November, 2019; Published: March, 2020

\section{Innledning}

Forskning innen kroppsøving viser at faget, slik det blir undervist i dag, i stor grad har en tradisjonell tilnærming som favoriserer visse elevgrupper og marginaliserer andre (Fitzpatrick, 2013; Gerdin, 2016; Gerdin et al., 2019; Öhman, Almqvist \& Meckbach, 2014). Säfvenbom, Bulie \& Haugen (2015) fant for eksempel at idrettsaktive elever opplever større tilhørighet til faget enn de som ikke driver med organisert idrett på fritiden. Studier viser også at gutter finner seg bedre til rette i kroppsøving, med de aktiviteter og undervisningsformer som preger undervisningen, enn jenter. (Moen, Westlie, Bjørke \& Brattli, 2018). Dowling (2016) betrakter «kroppsøvingsfaget som en arena for de idrettsflinke og trente» (s. 260), og hevder at faget derfor kan bidra til å forsterke sosiale forskjeller. Både nasjonal og internasjonal forskning viser derfor at kroppsøving kan bidra til å skape både innenforskap og utenforskap, noe som fører til faglige utfordringer. Standal (2015) framhever derfor viktigheten av en inkluderende undervisning i faget. Han er tydelig på at inkludering i kroppsøving (som i annen undervisning) handler om å utvikle gode læringsrom som omfavner alle elever, snarere enn tiltak rettet mot enkeltelever. Inkluderende undervisning er både en praksis og en prosess som krever refleksjon blant skoleledere og lærere, med sikte på å øke deltakelsen, øke fellesskapet, øke demokratiseringen og øke læringsutbyttet for alle elever (Haug, 2004; Standal, 2015).

Noen studier har sett nærmere på forhold som fremmer sosial inkludering. Larson og Silverman (2007) framholder viktigheten av at kroppsøvingslæreren viser omsorg for sine elever, og da særlig gjennom at læreren kjenner elevene sine godt.Videre fant Larson (2006) at elever ønsker å bli lagt merke til, få hjelp til å lære, og at elevene anser det som viktig at læreren stoler på og respekterer dem. Dette understøttes av McCuaig, Öhman og Wright (2013) som framhever at i inkluderende undervisning bør kroppsøvingslærere ha større fokus på individualisering, samvær og oppmuntring. Lyngstad, Hagen og Aune (2016), som har studert årsakene til skjuleteknikker i kroppsøving, mener at undervisningen må ha en klar oppgaveorientering basert på konstruktive læringsprosesser for å fremme inkludering i faget. Goodwin og Watkinson (2000) finner at elever beskriver de "gode dagene» i kroppsøvingsfaget som dager preget av en opplevelse av tilhørighet, ferdighetsbasert deltakelse og et læringsutbytte som hos resten av klassen. 
Forskningen tegner slik sett et bilde av hvordan undervisning i kroppsøving både kan inkludere og ekskludere elever og elevgrupper. Studier som gir innblikk i hvordan kroppsøvingslærere som lykkes med en sosialt inkluderende praksis faktisk jobber og tenker, er imidlertid mangelvare. Med bakgrunn i denne erkjennelsen valgte vi i EDUHEALTH å studere lærere som uttalt ønsker å jobbe sosialt inkluderende i faget (Gerdin et al., 2019; Schenker et al., 2019). Da dette er et internasjonalt samarbeidsprosjekt mellom forskere fra Sverige, Norge og New Zealand bruker prosjektgruppen begrepene «social justice» og "social just pedagogies», snarere enn de norske begrepene "sosialt inkluderende» og "sosialt inkluderende undervisning» som vi anvender i denne artikkelen. Uavhengig av språkdrakt er vi som pedagogisk orienterte forskere opptatt av den pedagogiske praksisen som fremmer sosialt inkluderende undervisning. Vi forstår sosialt inkluderende undervisning som at lærere i sin undervisningspraksis er opptatt av å ta hensyn til faktorer som kjønn, seksualitet, sosioøkonomiske forhold og etnisitet for å utjevne forskjeller og inkludere alle elever. Vi deler derfor Tinning (2012) sin forståelse av at sosialt inkluderende undervisning i kroppsøving er det som omfavner en etisk praksis, og et perspektiv på undervisning inspirert av kritisk teori (Lather, 1998). Dette er en pedagogikk som søker å gjenkjenne sosial ulikhet og handle på basis av dette, snarere enn å marginalisere grupper av elever ut fra for eksempel kjønn, seksualitet, etnisitet eller sosioøkonomisk status (Gerdin et al., 2019). Begrepene «social» og «justice» i relasjon til kroppsøving er utdypet ytterligere $\mathrm{i}$ en tidligere publisert artikkel fra prosjektet (Schenker et al., 2019).

I EDUHEALTH har vi gjennomført datainnsamlinger i Sverige, Norge og New Zealand. Denne artikkelen tar derimot kun utgangspunkt i datainnsamlingen gjennomført i New Zealand våren 2018, og mer presist: observasjon og intervju med en kroppsøvingslærer, «John» [pseudonym]. Målet med artikkelen er å forstå hvilken kunnskap og innsikt om elever som ligger til grunn for hans måte å jobbe sosialt inkluderende i faget på. For å få forståelse om dette har vi søkt støtte i Urie Bronfenbrenners utviklingsøkologiske modell (Bronfenbrenner, 1996) som analytisk rammeverktøy. Før vi utdyper teori, metode og funn, vil vi gi litt bakgrunnskunnskap om New Zealand.

\section{New Zealand: Samfunnskontekst, skolekontekst og skolefaget «Health and Physical Education (HPE)»}

Sverige, Norge og New Zealand (sammen med Australia) har det til felles at sosialt-kritiske perspektiver og sosial rettferdighet står sterkt i læreplanene i kroppsøving (Culpan \& Bruce, 2007). Gjennom våre utvekslingsopphold i New Zealand, Sverige og Norge, har vi imidlertid fått mer innsikt i både likheter og forskjeller mellom de tre landene når det gjelder samfunnsstrukturer, skolesystem og i kroppsøvingsfaget (Gerdin et al., 2018). I denne artikkelen er det ikke disse ulikhetene som vies oppmerksomhet, og vi vil derfor ikke gi en inngående kontekstuell beskrivelse av New 
Zealand. I og med at læreren vi beskriver i denne artikkelen jobber i New Zealand, vil vi likevel presentere et lite bakteppe av informasjon.

Som i verden for øvrig, har New Zealand gått i retning av økende individualisme og fri konkurranse, også innenfor skolesektoren (Apple, 2001). Samfunnet er svært sammensatt når det gjelder sosiale, kulturelle, og særlig økonomiske forhold (France \& Roberts, 2017). I tillegg til «the Kiwis» ${ }^{1}$ og maoriene (urbefolkningen), har landet også en betydelig migrasjon fra Stillehavsøyene, «Pacific Islanders». En økende individualisme, sammen med privatisering, har blant annet ført til økende sosial ulikhet. Som i Norge er lav sosioøkonomisk status assosiert med problemer som familievold, økende overvekt og mentale helseutfordringer (Dahl, Bergsli \& van der Wel, 2014). Dette er særlig utbredt blant maoriene og blant Pacific Islanders (Ministry of Health, 2017). Som en hovedregel går alle barn og unge i New Zealand på skole fra de er 6 til 16 år. Det er en blanding av private og offentlige skoler i landet. I de private skolene finner en ofte kjønnsdelt undervisning, mens i de offentlige er kjønnsblanding det vanligste. Alle offentlige skoler rangeres i 10 ulike sosioøkonomiske kategorier, såkalte «deciles» (hvor 10 er høyest og 1 er lavest). Decile bestemmes av fem ulike indikatorer (foreldregruppens inntekt og utdanning, husholdningenes størrelse, grad av yrkesdeltakelse og antall mottakere av sosialhjelp) (Ministry of Education, 2018a, b).

Læreplanen i HPE legger, i likhet med den generelle delen av læreplanen, vekt på sosial-kritiske perspektiver som inkluderer prinsipper for sosial rettferdighet og det å anerkjenne mangfold (Ministry of Education, 2007). Til forskjell fra Norge er ikke læreplanen i New Zealand et forskriftspålagt styringsdokument. Det betyr at en kroppsøvingslærer i New Zealand ikke er juridisk bundet til å følge læreplanen.

\section{Å forstå en kroppsøvingslærers pedagogiske arbeid gjennom Bronfenbrenners utviklingsøkologiske modell}

Bronfenbrenners utviklingsøkologiske modell er en sosialpsykologisk teori som er relevant når man skal se på hvordan individer sosialiseres inn i en kultur (Bronfenbrenner, 1996). Modellen tar utgangspunkt i individet, for så å beskrive de kontekstuelle faktorene som påvirker individet på ulike nivåer. Gjennom modellen tar Bronfenbrenner avstand fra psykologiens ensidige fokus på individ løsrevet fra kontekst. På samme tid er han også kritisk til hvordan sosiologien tar inn strukturelle forståelser av sosiale fenomeners determinerende virkning på individet (Bronfenbrenner, 1996).

Bronfenbrenners økologiske utviklingsmodell har derfor til hensikt å forstå hvordan individ og omgivelser gjensidig påvirker hverandre. Det er fire nivåer som Bronfenbrenner mener er sentrale for å forstå hvilke kontekster et hvert individ inngår i.

\footnotetext{
${ }^{1}$ Kiwis brukes i dagligtale som en fellesbetegnelse på newzealendere som ikke tilhører urbefolkningen.
} 
Det første er mikronivået, som beskriver de påvirkningene som befinner seg nærmest individet, og som individet er i direkte kontakt med. Dette handler om relasjoner som individet kjenner gjennom lengre tid, eller bekjentskap som stadig er tilgjengelige for kontakt. Mikronivået hos Bronfenbrenner er således parallelt med det Berger, Wiik og Luckmann (2011) omtaler som ansikt-til-ansikt-situasjonen. Eksempler på mikronivå kan være familie, venner, skole, barnehage og idrettslag. Det neste nivået er mesonivået, som beskriver samspillet mellom ulike nærmiljøer på mikronivå. Med andre ord, alle relasjoner som direkte påvirker individet. Eksempler kan være skole-hjemsamarbeid, venners deltakelse i idrettslag og venners relasjon til andre venner. Deretter kommer eksonivået, som beskriver ulike formelle og uformelle samfunnsinstitusjoner i lokalmiljøet, og som påvirker individet direkte og indirekte. Dette kan f.eks. være hvordan kommunen har lagt til rette for fritidstilbud og hvordan dette påvirker oppvekstmiljøet. Andre eksempler på eksonivå kan være hvordan arbeidslivet lokalt fungerer. Er det for eksempel stor arbeidsløshet, eller preges lokalsamfunnet av pendling eller fraflytting? Dette er også forhold som griper inn den enkeltes livsverden. Til slutt har vi makronivået, som beskriver strukturelle forhold på samfunnsnivå som økonomisk system, utdanningssystem, rettsvesen og politisk styringssystem (Bronfenbrenner, 1996). Relatert til skolen, elever og læreres skolehverdag, vil alle de fire nivåene være virksomme på ulikt vis og med ulik tyngde, til ulik tid. Det sentrale for Bronfenbrennner er at vi må forstå at individ og sosialiseringsinstanser virker i et samspill.

For å identifisere den kontekstuelle elevkunnskapen som læreren i denne studien gjorde seg nytte av for å ta sosialt inkluderende undervisningsvalg, søkte vi derfor støtte i den økologiske utviklingsmodellen (Bronfenbrenner, 1996). Modellen hjalp oss også å fortolke lærerens refleksjoner rundt samspillet (den gjensidige påvirkningen) mellom individet (eleven) og de ulike nivåne (omgivelsene).

\section{Metode}

EDUHEALTH-prosjektet involverer observasjon av undervisning og intervju med kroppsøvingslærere. Selv om prosjektet har som mål å gjøre komparative analyser mellom de tre involverte landene, er dette ikke et mål med denne artikkelen, da den kun tar for seg én lærer som jobber i New Zealand. Prosjektet har i sin helhet fătt etisk godkjenning $i$ alle tre land.

\section{Utvalg}

I New Zealand observerte og intervjuet vi til sammen seks kroppsøvingslærere. Disse lærerne var rekruttert inn i prosjektet som gode eksempler på lærere som jobber sosialt inkluderende i faget på bakgrunn av hvordan vi som forskergruppe forstår sosialt inkluderende undervisning (se innledningen). I New Zealand var det de newzealandske forskerne som rekrutterte lærere til å delta i prosjektet. Som lærerutdannere ved Auckland University har de et nært samarbeid med kroppsøvingslærere 
som blir benyttet som øvingslærere ved universitet. På bakgrunn av denne kjennskapen til praksisfeltet, rekrutterte forskerne det de anså som relevante lærere for prosjektet. Studien baserer seg derfor på et strategisk utvalg av lærere (Bryman, 2003). I New Zealand ble sju lærere kontaktet, og seks hadde anledning til å delta. Disse lærerne underviste ved fire ulike offentlige, kjønnsblandede skoler, og utvalget besto av skoler ranket med både «høy» og «lav» decile (fra decile 1 til decile 10). Læreren som omtales i denne artikkelen, John (pseudonym), jobber ved en "decile 1» skole $\mathrm{i}$ utkanten av en storby i New Zealand. John er en mannlig lærer på 33 år med indisk bakgrunn. Han har jobbet som kroppsøvingslærer i 5 år ved denne skolen og ble utdannet som kroppsøvingslærer i 2009. Skolen har ca. 2000 elever i aldersgruppen 13-19 år (klassetrinn 9-13), bestående av 30 ulike nasjonaliteter, men hovedvekten av elevene er maorier og Pacific Islanders. Vi observerte en 10. klasse med 23 elever, 8 jenter og 15 gutter. I lys av prosjektets overordnede mål om å lære av de gode eksemplene på å jobbe sosialt inkluderende $\mathrm{i}$ faget, var det i denne observasjonen særlig hvordan John inkluderte eleven «Warren» (pseudonym) i undervisningen, som fanget vår interesse. Data til artikkelen er generert med utgangspunkt i observasjoner fra en kroppsøvingstime (90 minutter), og intervju med John i etterkant av timen.

\section{Datainnsamling}

Datainnsamlingen i New Zealand ble gjennomført i april 2018. To forskere fra New Zealand, to fra Norge og fire fra Sverige deltok. Vi gjennomførte i alt 10 observasjoner og 6 intervjuer med lærere (2 lærere ble observert i to økter). I forkant av datainnsamlingen hadde forskergruppen gjort pilotstudier (både observasjoner og intervju) i de tre respektive landene. Basert på pilotstudiene justerte vi intervjuguiden og observasjonsskjemaet som ble benyttet i datainnsamlingen for prosjektet.

Alle observasjoner med påfølgende intervjuer ble gjennomført av et team bestående av forskere fra hver av de tre nasjonene. Under observasjonen og intervjuet med John bestod teamet av en kvinnelig svensk forsker, en mannlig forsker fra New Zealand og en mannlig forsker fra Norge (førsteforfatter).

I EDUHEALTH har vi benyttet det Tripp (2012) omtaler som «critical incident technique» (CIT) som observasjonsmetode. CIT-metoden er relevant når hensikten er å studere vesentlige/avgjørende hendelser (critical incidents) i et undervisningsforløp (Colnerud, 1997, 2014) og læreres beslutningstaking (Tripp, 2012). Basert på teori om sosialt inkluderende undervisning, og særlig kunnskap om at ulike grupper kan stå i fare for å bli marginalisert i faget (Dowling, 2016; Gerdin, 2016; Säfvenbom, Haugen \& Bulie, 2014), utviklet vi et observasjonsskjema som hjalp oss å identifisere hendelser der lærerne jobbet sosialt inkluderende. Observasjonsskjemaet ga rom for at hver enkelt forsker kunne nedtegne utdypende beskrivelser av relevante hendelser, snarere enn lukkede kategorier. Å identifisere slike hendelser er det som innenfor CIT-metoden omtales som å fange opp "Captured incidents» (heretter cap's). Tematikker knyttet til blant annet kjønn, etnisitet, kultur, demokrati og sosial bakgrunn var 
i forgrunnen av vår oppmerksomhet for å fange opp cap's. I lys av disse tematikkene var vi i observasjonene også opptatt av å få øye på hvordan lærerne utøvet en inkluderende lærerrolle i møte med sine elever. I denne studien handlet identifisering av cap's om alt fra én spesiell hendelse i løpet av timen (for eksempel bruk av utstyr, hvordan en lærer håndterer en konflikt som oppstår mellom elever, hvordan læreren bruker kroppsspråk i undervisningen, valg av aktiviteter i undervisningen, endring av regler i en aktivitet, etc.), så vel som hele timen sett under ett (innhold, oppbygging, undervisningsmetode, etc.). Våre observasjoner var med andre ord innrettet mot lærerens pedagogisk inkluderende praksis.

Under selve observasjonen jobbet forskerne individuelt, og gjorde seg sine egne notater. Da timene var ferdige samsnakket forskerteamet om det hver enkelt hadde identifisert som sine cap's, før vi ble enige om hvilke som skulle følges opp i intervjuet med læreren.

I CIT-metoden skilles det som nevnt mellom "captured incidents» (cap's) og "critical incidents» (cit). "Captured incidents» er det som identifiseres under observasjonen, og som observatøren (forskeren) anser som relevant for forskningsspørsmålet. For å endre status fra en "cap's» til en "cit», kreves imidlertid en dypere forklaring bak hendelsen (Tripp, 2012). Med andre ord, når læreren gjennom intervjuet kunne forklare og reflektere rundt de bakenforliggende forhold knyttet til det vi hadde indentifisert som en cap's, kunne hendelsen skifte karakter til en cit.

Intervjuene i studien var "stimulated-recall interviews» (Lyle, 2003) og hadde til hensikt å gi kroppsøvingslærerne mulighet til å utdype hvordan de jobbet sosialt inkluderende. Intervjuguiden besto av fire generelle spørsmål som ble stilt alle lærerne (hva som var hensikten med timen, om dette var en typisk time, om dette var en time innenfor et større emne, samt hvilke deler av timen de selv mente å jobbe sosialt inkluderende). Etter å ha besvart disse tok den som ledet intervjuet utgangspunkt i de cap's forskere som ønsket at læreren skulle utdype. Intervjuene foregikk umiddelbart etter observasjon av timen/e på et møterom, et lærerværelse eller i en gymsal. De varte mellom 30 og 50 minutter, ble tatt opp på lydbånd og deretter transkribert. Intervjuene i New Zealand forgikk på engelsk. Intervjuet med læreren John varte i 50 minutter og foregikk på et møterom.

I den videre presentasjonen forholder vi oss både til de cap's vi indentifiserte under observasjonene, sammen med lærerens utdyping av disse presentert som sitater, altså

cit. I framskriving av observasjonene indikerer vi hver cap's med nummer; cap-1, cap-2 osv.

\section{Analyse}

Analysene begynte med at begge forfatterne gjorde en individuell gjennomlesing av observasjonsnotatene som var nedtegnet av de tre forskerne i prosjektet. Dette var for å skape et bilde av hva som sto fram som sosialt inkluderende praksis i denne timen. Deretter diskuterte vi i fellesskap, og kom fram til at det var særlig John sitt møte med eleven Warren som var det mest framtredende eksempelet på en sosialt inkluderende 
undervisningspraksis i denne timen. Denne delen av analysen er skrevet fram som en fortelling fra timen basert på de identifiserte cap's.

Intervjuet leste vi også hver for oss og foretok en nærlesing, der vi ønsket å få øye på hva og på hvilken måte John utdypet de cap's vi hadde identifisert som relevante. Nærlesing omtales som «(...) a technically informed, fine-grained analysis of some piece of writing, usually in connection with some broader question of interest» (Smith, 2016, s. 58). Vår nærlesing var derfor konsentrert rundt de delene av intervjuet som tok for seg de relevante og identifiserte cap's. Deretter sammenstilte vi våre analyser fra hver vår nærlesing, og det var tydelig for begge forfatterne at John framstod som en nærværende lærer. Han trakk på kunnskap om sine elever og de omgivelsene de var en del av, både i og utenfor skolen. På dette tidspunktet i analysen inkluderte vi Bronfenbrenners teori for hjelpe oss med å identifisere og fortolke den kontekstuelle kunnskapen som var virksom når læreren fattet sine undervisningsvalg. Modellen bidro også til å forstå lærerens refleksjoner rundt samspillet mellom individ og omgivelser.

Selv om analyser bygd på én observasjonsenhet ikke gir grunnlag for generalisering av kunnskap, kan kunnskapsbidraget være relevant i en forskningskontekst, men også mer allment pedagogisk (Cronin \& Armour, 2015; Kvale \& Brinkman, 2009; van Manen, 2002).

\section{Pedagogisk arbeid i kroppsøving: Fra individ til samfunn - fra samfunn til individ}

I det følgende vil vi først beskrive hva vi observerte i kroppsøvingstimen knyttet til lærerens pedagogiske arbeid i møte med eleven Warren. Dette framstiller vi som en kondensert fortelling fra timen, gjennom de observerte cap's. I den påfølgende diskusjonen utdyper vi cap's med intervjusitater fra læreren. Når cap's blir utdypet av læreren endrer de form og blir "critical incidents». De identifiserte cit søker vi så å forstå og diskutere ved hjelp av Bronfenbrenners teori. Til slutt diskuterer vi forbindelseslinjer og relevans av våre funn fra New Zealand til en norsk skole- og kroppsøvingskontekst.

\section{Fortelling fra en observasjon av en kroppsøvingstime i New Zealand}

I forkant av observasjon fikk vi opplyst at elevene i denne klassen var på slutten av en 9 ukers periode hvor de hadde jobbet med relasjonskompetanse i kroppsøving. Klassen hadde selv bestemt at de skulle fokusere på ferdighetene kommunikasjon, ledelse, teamarbeid og fair play.

I timen vi observerte brukte de leken «Capture the flag» (som også blir mye brukt i Norge), for å fremme relasjonskompetansen gjennom lagarbeid. Ved oppstarten av timen kommer en av elevene, Warren, en stor og kraftig maorigutt, bort til læreren og sier: «Sir, sir! Jeg har en lapp til deg her». Lappen var en legeattest som fritok ham fra å delta i kroppsøving (cap-1). Ganske raskt ser vi at læreren likevel inkluderer Warren 
i timen som sin «assistent» (cap-2). Mens læreren samler klassen, går gjennom mål for timen og har en innledende samtale om de fire fokusområdene kommunikasjon, ledelse, teamarbeid og fair play, er Warren i gang med å merke banen. Han legger for dagen en stor innsats slik at banen skal bli fin, at det er lik avstand mellom merkekjeglene, at linjene er rette og at banehalvdelene like store. Da aktiviteten begynner, veksler læreren mellom å veilede lagene og fordele nye ansvarsoppgaver til Warren. Vi legger merke til at læreren ikke hever stemmen sin en eneste gang i løpet av timen (cap-3). Snart får Warren også overta fløyta og får rollen som dommer (cap-4). Til å begynne med er han veldig forsiktig, men læreren gir ham stadige oppmuntringer, ros og veiledning (cap-5). Under pauser i spillet samler læreren lagene rundt seg til veiledning, og de sitter alle sammen på gulvet (cap-6). Kommunikasjonen mellom lærer og elever foregår hele tiden rolig, og med lave stemmer. Alle elevene får slippe til i samtalen rundt taktiske disposisjoner i spillet. Warrens ansvarsoppgaver blir også utvidet i løpet av timen etter hvert som han lykkes bedre og bedre som «veiledende dommer». Mot slutten av timen er han også «assisterende coach» for det ene laget (cap-7).Vi legger merke til at Warrens kroppsspråk endrer seg i løpet av timen. Fra å framstå som en litt sky og innesluttet gutt, åpner han seg både kroppslig og verbalt. Han gir oppmuntrende tilrop, blåser i fløyta, smiler og spøker med både lærer og medelever (cap-8).

\section{Lærerens pedagogiske arbeid: Balansekunsten å utnytte kontekstuell kunnskap og elevkunnskap}

Som nevnt hevder Haug (2004) og Standal (2015) at inkluderende undervisning er både en praksis og en prosess. Dette krever refleksjon blant skoleledere og lærere som ønsker å øke deltakelsen, fellesskapet, demokratiseringen og læringsutbyttet for alle elever. Våre observasjoner viser på ulikt vis hvordan John utøver en sosialt inkluderende undervisningspraksis. De refleksjoner han la til grunn for dette fikk vi videre utdypet giennom intervjuet.

Våre analyser viser at John var oppriktig interessert i sine elever. Dette kom til uttrykk gjennom måten han inkluderte Warren som assistent og dommer i timen (cap-2, cap-4), måten han kommuniserte med elevene sine og ikke minst hvordan han snakket om elevene sine i intervjuet. Følgende sitat gir også innblikk i hvem og hva han hadde fokus på i sin undervisningspraksis:

Jeg ønsker å fokusere på de elevene som er litt stille, de som ikke viser best innsats. Gi dem mestringsopplevelser og få dem til å tenke: «Dette fikk jeg til bra», og dermed gi dem en eierfølelse til egen læringsprosess.

Sitatet viser at han var særlig opptatt av å møte de elevene som faller utenfor i kroppsøving. Dowling (2016) omtaler kroppsøving som et fag for de idrettsflinke og trente. Sitatet over uttrykker imidlertid at John også har et fokus på de som kanskje faller utenfor og blir marginalisert. I tråd med Standal (2015) sin forståelse av inkluderende undervisning, viser John at han søker å øke læringsutbyttet for alle sine elever. 
Et annet trekk vi merket oss ved Johns pedagogiske praksis, var at han ikke hevet stemmen en eneste gang i løpet av økta vi observerte (cap-3, cap-6). Hans framtoning overfor elevene var likevel tydelig. Det var aldri tvil om hvem som var klassens leder (lærer). I likhet med funn fra Larson og Silverman (2007) ser vi at John også viser omsorg for sine elever, og samtidig utstråler en ro og en respekt i møte med dem. I intervjuet etter observasjonen løftet vi fram det vi hadde identifisert (cap-3, cap-6), og han responderte som følger:

Jeg hever aldri stemmen ... . Jeg tror ikke jeg noen gang har skreket i løpet av mine fem år her [ved denne skolen]. Og elevene forstår, de respekterer det. De får nok av det [skriking og kjeft] hjemme. De får kjeft i kirken, på trening og i fritida.

Våre observasjoner viser at læreren har en god relasjon med sine elever på det Bronfenbrenner omtaler som mikronivå. Gjennom intervjuet forstår vi at John jobber bevisst med å bygge opp slike gode relasjoner på mikronivå, noe som samsvarer med McCuaig, Öhman og Wrights (2013) forståelse av en inkluderende undervisningspraksis. I tillegg til at John jobber med å opparbeide slike relasjoner, viser sitatet over at han også har en tydelig bevissthet om at han som lærer ønsker å representere noe annet for sine elever enn det mange av dem opplever i andre relasjoner de står i (foreldre, søsken, kirken, etc.). Med andre ord, læreren søker å være en alternativ rollemodell gjennom å anvende en annen kommunikasjonsform overfor elevene (cap-6) enn det de opplever ellers. En slik refleksjon fra lærerens side fordrer at han har kjennskap til sine elever og deres utviklingsøkologiske miljø. Det er her vi mener å identifisere at en sosialt inkluderende undervisning krever at læreren både ser individet, og samtidig anser relevansen av kunnskap om individet som del av en større kontekst. Læreren bruker sin kunnskap om ulike relasjoner fra elevenes nærmiljø aktivt i møte med dem. Disse relasjonene mellom de ulike nærmiljøene, både hjemme og på skolen, befinner seg på Bronfenbrenners mesonivå (Bronfenbrenner, 1996).

I intervjuet kom det fram at John kjente til at Warren og tre andre gutter i klassen var under oppsyn av politiet. John fortalte at de hadde vært utvist fra skolen for gjengkriminalitet. I selve intervjuet trakk vi som forskere også fram våre observasjoner der vi spesielt hadde lagt merke til hvordan han håndterte Warren i timen (cap $1,2,4,5,6,7)$. Gjennom intervjuet fikk vi dermed en dypere innsikt i hvordan og hvorfor John jobbet med å inkludere Warren spesielt, og elevene generelt.

Jeg begynte som seksjonsleder på denne skolen, så jeg har mye kunnskap gjennom det å jobbe veiledende med elever. Så for meg å ha en samtale med elevene, da må jeg bare ned på deres nivå. De vet fortsatt at jeg er læreren og de elevene. Men det at jeg ikke snakker til dem foran klassen ... men når klassen er opptatt med annet, at jeg tar entil-en samtalen da. Gjør det til en positiv spiral - «at jeg ønsker at du endrer deg». Dette er det du gjør, dette er det som skjer, og så sette dem selv i sentrum, før jeg kommer tilbake og sier; nå er du brilliant! Og jeg trenger å se flere briljante øyeblikk.

Sitatet viser en lærer som, basert på refleksjon og kunnskap om sine elever på både individ og samfunnsnivå, jobber med å inkludere dem i undervisningen med mål 
om å øke deltakelse, fellesskap, demokratisering og dermed deres læringsutbytte. Til forskjell fra tidligere studier som viser at kroppsøvingsfaget og lærere favoriserer visse grupper framfor andre, for eksempel basert på idrettsbakgrunn eller kjønn (Fitzpatrick, 2013; Gerdin, 2016; Gerdin et al., 2019; Öhman, Almqvist \& Meckbach, 2014; Säfvenbom, Bulie \& Haugen, 2014), finner vi at John er opptatt av elevene som enkeltindivider, med de historier hver og en har med seg inn i skolen og timen. At vi som forskere fikk innsikt $i$ at John hadde en historie å fortelle om Warren og de andre guttene som ligger utenfor skolekonteksten (at de var i politiets oppsyn), viser at læreren hadde kunnskap om hvordan eksonivået (politiet) grep direkte inn i hverdagen til disse guttene. Mer konkret; at guttene var i politiets søkelys var noe som påvirket livene til disse guttene, og dermed også skolehverdagen. Våre analyser viser at John som lærer var tydelig på to ting i denne sammenheng: 1) at det er viktig å ha kunnskap om elevene, og 2) at nettopp fordi han har slik kunnskap mener han det er svært viktig å etablere et personlig autoritetsforhold med dem. Med andre ord, læreren bruker de kontekstuelle faktorene som påvirker elevene, både på og utenfor skolen, aktivt som kunnskapsgrunnlag i sitt pedagogiske arbeid med elevene. Tidligere forskning framhever at elever ønsker å bli sett (Larson, 2006; Larson \& Silverman, 2007), og til å få en opplevelse av tilhørighet, ferdighetsbasert deltakelse og et læringsutbytte på linje med resten av klassen (Goodwin \& Watkinson, 2000). Selv om vår studie ikke gir innsikt i elevens opplevelser, er det tydelig at læreren jobber med å se sine elever gjennom å utvikle et nært forhold til dem.

Den overbyggende kontekstuelle kunnskapen han som lærer har med seg inn i sitt arbeid med den enkelte elev, er at skolen han jobber ved ligger i en bydel med store sosioøkonomiske og kulturelle utfordringer. Som nevnt er de fleste av elevene ved skolen Pacific Islanders eller maorier. Det betyr at flere av klassene er "non-white», som det heter i New Zealand. Et trekk hos maoriene - og andre stillehavskulturer - er et tradisjonelt kjønnsrollemønster. Gjennom intervjuet ble det tydelig at John har god kjennskap til dette, som i Bronfenbrenner sin terminologi betegnes som makronivået. Han reflekterte for eksempel over problemstillinger knyttet til kjønnsroller i undervisningen:

Jeg prøver å ha aktiviteter hvor det... Mine elever vet at vi ikke spiller rugby. Vi har ballspill, men det vil ikke være på den konvensjonelle måten hvor guttene får dominere.

Sitatet viser at John bevisst ikke inkluderer rugby som «ferdig spill» i timen. I New Zealand er rugby først og fremst en idrett for gutter/menn (Fitzpatrick, 2013; Gerdin, 2016). Denne kunnskapen har John, og han bruker den bevisst i måten han tar rugby som spill i sin undervisning. Sitatet viser at hans intensjon er å bruke ballspill på en måte som vil inkludere snarere enn å marginalisere jentene. Våre analyser viser at han har en særlig bevissthet knyttet til kunnskap på makronivå. Han trekker på innsikt om samfunnsmessige faktorer som omgir elevene, både fra den newzealandske verdibasen, men også det som eksplisitt angår de elevene John har i sin klasse (Pacific Islanders og maorier). 
Gjennom kunnskap på makronivå, sammen med kunnskap på mikro-, meso- og eksonivå, og refleksjon over samspillet mellom disse, skaper John et utgangspunkt for en sosialt inkluderende undervisningspraksis som kan bidra til å øke fellesskap, demokratisering og læring for alle elever (Standal, 2015).

\section{Er funn generert i New Zealand relevant for norsk kontekst - og for norske kroppsøvingslærere?}

I denne artikkelen har vi tatt for oss et godt eksempel på sosialt inkluderende kroppsøvingsundervisning i New Zealand. New Zealand er et land som både i samfunnskontekst, politisk styring og skolepolitisk skiller seg fra det norske systemet, selv om det også er klare likheter. Vi mener de funn vi har skrevet fram i denne artikkelen er av pedagogisk interesse og har relevans for en norsk kontekst. I alle tre land involvert i EDUHEALTH har skolen i sitt samfunnsmandat å utjevne sosiale ulikheter. I likhet med New Zealand er også den norske skolen preget av en sammensatt elevgruppe fra ulike nasjonaliteter og ulike samfunnslag. Selv om vi i Norge ikke har en tydelig «decile-inndeling» av skolene slik New Zealand har, er det på det rene at vi til en viss grad har A- og B-skoler i Norge, basert på sosioøkonomiske forskjeller. Den såkalte skolebidragsstatistikken er et eksempel på en slik rangering av skoler i Norge (Udir, 2018). Læreren og eleven vi beskriver i denne artikkelen er fra en skole i New Zealand der de opererer med kjønnsblandet undervisning, slik vi er kjent med i Norge.

Selv om denne artikkelen bygger på data fra New Zealand, mener vi den er relevant i norsk kontekst fordi deler av en lærers pedagogiske praksis må forstås som generell, og ikke kontekstuell. Det er en grunnleggende og generell forståelse at lærergjerningen skal bygge sin undervisningspraksis på et menneskesyn basert på likeverd; at læreren ser alle sine elever og behandler dem med respekt. Tidligere forskning, både nasjonal og internasjonal, viser imidlertid at kroppsøvingsfaget oppleves som marginaliserende for enkelte elever og for enkelte grupper. I denne studien har vi vist hvordan en lærer søker å jobbe sosialt inkluderende; å se alle uavhengig av kjønn, seksualitet, sosioøkonomisk bakgrunn eller idrettsbakgrunn. Studien frambringer slik sett generell kunnskap som kan være relevant og anvendes uavhengig av kontekst (land).

Videre mener vi at artikkelens teoridrevne analyse er relevant for norske kropps-øvingslærere, studenter og lærerutdannere som et utgangspunkt for å reflektere over egen og andres pedagogiske arbeid med sosialt inkluderende undervisning $\mathrm{i}$ faget. Selv om Bronfenbrenners økologiske utviklingsmodell er en godt etablert teori, er den i liten grad benyttet som analytisk rammeverk innen kroppsøvingsforskning i Norge, og kan slik sett bidra med et nytt perspektiv i forståelsen av pedagogisk arbeid i faget.

\section{Sammenfattende refleksjoner}

Denne artikkelen bygger på observasjon (critical incident technique [Tripp, 2012]) og intervju (stimulated recall interview, [Lyle, 2003]) med en kroppsøvingslærer i 
New Zealand som har et uttalt mål å jobbe sosialt inkluderende i sin undervisning. Vi har benyttet Bronfenbrenners utviklingsøkologiske modell (Bronfenbrenner, 1996) som analytisk rammeverk for å identifisere hvordan lærerens undervisningspraksis er basert på kunnskap om elever på individ-, gruppe- og samfunnsnivå, samt refleksjoner over samspillet mellom disse nivåene. Våre analyser viser at «vårt gode eksempel» på en lærer som jobber sosialt inkluderende er 1) at læreren har kunnskap om hvordan de ulike nivåene står i et gjensidig påvirkningsforhold med elevene og 2) at læreren handler på bakgrunn av denne kunnskapen i sitt pedagogiske arbeid. Vår studie viser med andre ord at inkluderende undervisning er både en praksis og en prosess som krever refleksjon på mikro-, meso-, ekso- og makronivå. For å øke deltakelsen, fellesskapet, demokratiseringen og læringsutbyttet for alle elever (Haug, 2004; Standal, 2015) må lærerens inkluderende handlingsvalg (undervisning) springe ut av faglige refleksjoner basert på kunnskap om elevene i skjæringspunktet mellom individ og samfunn.

\section{Forfatteromtale}

Knut Westlie er førstelektor i profesjonsrettet pedagogikk ved Høgskolen i Innlandet, hvor han underviser på bachelor- og masterutdanningene i kroppsøving og idrett. Han har arbeidet som lærer i grunnskolen i over 20 år. Hans forskningsinteresser ligger i skjæringspunktet mellom pedagogikk og sosiologi med fokus på skole og kroppsøving.

Kjersti Mordal Moen er professor i kroppsøving ved Seksjon for idrett og kroppsøving ved Høgskolen i Innlandet. Moen har spesiell kompetanse innenfor kroppsøvingslærerutdanning, praksis i kroppsøvingslærerutdanning, samt skolefaget kroppsøving. Hun leder forskningsgruppen Teaching and Learning in Physical Education ved Høgskolen i Innlandet, og har ledet flere større forskningsprosjekter. Hun veileder doktorgradsstudenter innenfor kroppsøving.

\section{Kreditering}

Denne artikkelen har mottatt støtte fra EU giennom forskningsprogrammet Horizon 2020. Vi vil også takke våre samarbeidspartnere Rod Philpot og Wayne Smith ved University of Aukland, NZ, samt Göran Gerdin, Lena Larsson, Katarina Schenker og Susanne Linnér ved Linnéuniversitetet i Sverige.

\section{Referanser}

Apple, M. W. (2001). Comparing Neo-liberal Projects and Inequality in Education. Comparative Education, 37(4), 409-423. https://doi.org/10.1080/03050060120091229

Berger, P., Wiik, F. \& Luckmann, T. (2011). Den samfunnsskapte virkelighet (5. opplag). Bergen: Fagbokforlaget. Bronfenbrenner, U. (1996). The ecology of human development: Experiments by nature and design. Cambridge, MA: Harvard University Press.

Bryman, A. (2003). Business research methods. Oxford: Oxford University Press. 
Colnerud, G. (1997). Ethical conflicts in teaching. Teaching and Teacher Education, 13(6), 627-635. https://doi. org/10.1016/S0742-051X(97)80005-4

Colnerud. G. (2014). Etikk i praksis. Nordic Journal of Applied Ethics, 8(2), 22-30.

Cronin, C. \& Armour, K. M. (2015). Lived experience and community sport coaching: A phenomenological investigation. Sport, Education and Society, 20(8), 959-975. https://doi.org/10.1080/13573322.2013.85 8625

Culpan, I. \& Bruce, J. (2007). New Zealand physical education and critical pedagogy: Refocusing the curriculum. International Fournal of Sport and Health Science 5(1), 1-11.

Dahl, E., Bergli, H. \& Wel, K. (2014). Sosial ulikhet $i$ helse: En norsk kunnskapsoversikt. Oslo: Høgskolen i Oslo og Akershus.

Dowling, F. (2016). De idrettsflinkes arena: Ungdoms fortellinger fra kroppsøvingsfaget med blikk på sosial klasse. I Ø. Seippel, M. K. Sisjord \& Å. Strandbu (Red.), Ungdom og idrett (s. 249-268). Oslo: Cappelen Damm Akademisk.

Dowling, F., Fitzgerald, H. \& Flintoff, A. (2015). Narratives from the road to social justice in PETE: teacher educator perspectives. Sport, Education and Society, 20(8), 1029-1047. https://doi.org/10.1080/13573322 .2013 .871249

Fitzpatrick, K. (2013). Brown bodies, racialisation and physical education. Sport, Education and Society, 18(2), 135-153. https://doi.org/10.1080/13573322.2011.559221

Gerdin, G., Philpot, R., Larsson, L., Schenker, K., Linnér, S., Moen, K., ... Legge, M. (2019). Researching social justice and health (in)equality across different school Health and Physical Education contexts in Sweden, Norway and New Zealand. European Physical Education Review, 25(1), 273-290.

Gerdin, G. (2016). The disciplinary and pleasurable spaces of boys' PE - The art of distributions. European Physical Education Review, 22(3), 315-335.

Goodwin, D. L. \& Watkinson, E. J. (2000). Inclusive physical education from the perspective of students with physical disabilities. Adapted Physical Activity Quarterly. 17, 144-160.

Haug, P. (2004). Finst den pedagogiske kompetansen det er bruk for i skulen? Spesialpedagogikk. 5, 4-11.

Kvale, S. \& Brinkman, S. (2009). Interviews: Learning the craft of qualitative research interviewing. Los Angeles, CA: Sage.

Lather, P. (1998). Critical Pedagogy and its Complicities: A Praxis of Stuck Places. Educational Theory, 48(4), 487-497.

Larson, A. (2006). Student perception of caring teaching in physical education. Sport Education and Society, 11(4), 337-352. doi:10.1080/13573320600924858

Larson, A. \& Silverman, S. J. (2007). Rationales and Practices Used by Caring Physical Education Teachers. Sport, Education and Society, 10(2), 175-193.

Lyle, J. (2003). Stimulated recall: a report on its use in naturalistic research. British Educational Research Journal, 29(6), 861-878.

Lyngstad, I., Hagen, P. M. \& Aune, O. (2016). Understanding pupils' hiding techniques in physical education. Sport, Education and Society, 21(8), 1127-1143, https://doi.org/10.1080/13573322.2014.993960

McCuaig, L, Öhman, M. \& Wright, J. (2013). Shepherds in the gym: employing a pastoral power analytic on caring teaching in HPE, Sport, Education and Society, 18(6), 788-806. doi: 10.1080/13573322.2011.611496

Ministry of Education (2007). The New Zealand Curriculum. Wellington, NZ: Learning Media Limited.

Ministry of Education (2018a, 12. desember). https://www.educationcounts.govt.nz/statistics/schooling/studentnumbers $/ 6028$

Ministry of Education (2018b). http:/www.education.govt.nz/school/running-a-school/resourcing/operationalfunding/school-decile-ratings/

Ministry of Health (2017). Annual Update of Key Results 2014/15: New Zealand Health Survey. http://hwww. health.govt.nz/publication/annual-update-key-results-2014-15-new-zealand-health-survey.

Moen, K. M. (red), Westlie, K. (red), Bjørke, L. \& Brattli, V. H. (2018). Når ambisjon møter tradisjon: En nasjonal kartleggingsstudie av kroppsøvingsfaget i grunnskolen (5.-10. trinn) (Vol. Nr. 1-2018, Oppdragsrapport/ Høgskolen i Innlandet). Elverum: Høgskolen i Innlandet. https://brage.inn.no/inn-xmlui/handle/11250/ 2482450

Säfvenbom, R., Haugen, T. \& Bulie, M. (2015). Attitudes toward and motivation for PE. Who collects the benefits of the subject? Physical Education and Sport Pedagogy, 20(6), 629-646. https://doi.org/10.1080/17 408989.2014.892063

Schenker, K., Linnér, S., Smith, W., Gerdin, G., Mordal Moen, K., Philpot, R., ... Westlie, K. (2019). Conceptualising social justice - what constitutes pedagogies for social justice in HPE across different 


\section{Kroppsøvingslareren som en inkluderende pedagog}

contexts? Curriculum Studies in Health and Physical Education, 10(2), 126-140. https://doi.org/10.1080/25 742981.2019 .1609369

Smith, B. H. (2016). What Was «Close Reading»? A century of Method in Literary Studies. Minnesota Review, 87 (New Series), 57-75. https://muse.jhu.edu/article/633173/pdf

Standal, Ø. F. (2015). Tilpassa opplæring og inkludering i kroppsøving. I G. Rugseth \& Ø. F. Standal (Red.), Inkluderende kroppsøving (s. 9-22). Oslo: Cappelen Damm Akademisk.

Tinning, R. (2012). A socially critical HPE (aka physical education) and the challenge for teacher education. I B. Down \& J. SMyth (Red.), Critical Voices in Teacher Education: Teaching for Social fustice in Conservative Times (s. 223-238). Dordrecht: Springer.

Tripp, D. (2012). Critical Incidents in Teaching: Developing Professional Judgement (2. utg.), London: Routledge. Udir.no (2018). https://skoleporten.udir.no/rapportvisning/videregaaende-skole/laeringsresultater/skolebidrag van Manen, M. (2002). Writing in the dark: Phenomenological studies in interpretic inquiry. London: The Althouse Press.

Öhman, M., Almqvist, J., Meckbach, J. \& Quennerstedt, M. (2014). Competing for ideal bodies: A study of exergames used as teaching aids in school. Critical Public Health, 24(2), 196-209. https://doi.org/10.1080 /09581596.2013.872771 